\title{
Investigating the Effect of Teams-Games-Tournament (TGT) Technique Towards Students' Speaking Skill
}

\author{
Tuty Handayani Gusadha ${ }^{1}$, Mukhaiyar $^{2}$, and Ratmanida ${ }^{3}$
}

\author{
${ }^{1}$ Universitas Negeri Padang, Padang, Indonesia, $ه$ (email), tutyhandayanigusadha@gmail.com \\ 2 Universitas Negeri Padang, Padang, Indonesia, $\triangle$ (email), ratmanida@gmail.com \\ ${ }^{3}$ Universitas Negeri Padang, Padang, Indonesia, $ه$ (email), $\underline{\text { mukhaiyar@gmail.com }}$
}

\begin{abstract}
This study aimed to investigate the effect of Teams-Games-Tournament (TGT) Technique towards students' speaking skill. Type of this research was a quantitative research with quasi-experimental design. 60 students of XI grade at SMA Negeri 9 Padang were choosed as the sample of this research which divided into two groups, experimental and control group. Both of this groups consisted of 30 students. The Teams-GamesTournament (TGT) Technique was used in the experimental group and the traditional technique was used in the control group to teach speaking. The data of this research were collected by using speaking test. It was used to obtain the students' speaking score. Then, the data was analyzed by using t-test formula with the significance alpha 0.05. The findings of the research showed that Teams-Games-Tournament (TGT) Technique give a better effect on students' speaking skill when compared with the effects of traditional technique. It was proved by the value of $\mathrm{t}_{\text {observed }}$ that was 2.446 which was higher than the value of $\mathrm{t}_{\text {table }}$ which was 1.671. The data indicated that the students taught by using Teams-Games-Tournament (TGT) Technique achieved significantly better scores in speaking than those taught by using the traditional technique.
\end{abstract}

\section{Keywords: Teaching Speaking, Speaking Skill, Teams-Games-Tournament (TGT) Technique}

\section{INTRODUCTION}

Speaking is a skill in English language besides reading, listening, and writing. Speaking has the important role as the tool of communication and also facilitates the process of language learning itself. Speaking skill is more difficult than the other since speaking happens in the real situation. Unlike reading, writing, and listening, speaking requires students to be able to produce sentences and respond the interlocutor in a real situation. It means, in speaking students should have the ability to turn-take in a conversation, create direct interaction appropriately and keep the conversation flowing. This complexity makes speaking skill often regarded as the most difficult English skill.

Speaking used as the tool of communication and become one of the most crucial skills for the human being. As Ur (1991:120) states that speaking is the most important skill compared with the other language skills (writing, listening, and reading ) because to learn about a certain language people will refer to the speakers of that language. The importance of this skill also stated by Brown and Yule (1983:10), they state that speaking is a productive skill which enables people to express their needs, requests, information, and services. Those activities obviously are the basic needs in human life to communicate each other. Therefore, we are not able to communicate well if do not have a good ability in speaking. Speaking ability can be said as the one of the important keys for success in any field.

In Indonesia, speaking is stated as one of the basic competencies for English subject at Senior High School. It is one of the four language skills learned at Senior High School besides listening, reading, and writing. Based on the basic competency, students are expected to comprehend the purpose, structure and also language features of various texts in speaking skill. In this research, the researcher focused on report text. Report text is one of the suitable texts for speaking skill because it requires students to describe and present information about something in general and specific terms. Describe and present information are kind of learning activities that compatible practiced in oral mode and will improve students speaking ability if conducted properly.

The complexity of speaking skill makes students faced many difficulties in the learning process and becomes a serious anxiety for them. According to Ur (1991:121) one of the problems in speaking activities is students are often inhibited about trying to speak in English because they are anxious to make mistakes and get criticism from the teacher and classmates. This problem makes students not able to think clearly and express their ideas well in speaking. It can become a serious threat in speaking learning process because it can be an obstacle for students to get successful in speaking skill. 
Another aspect that influence students' speaking skill is the technique used to teach speaking by the teacher. The teaching speaking activity is still done in a monotonous way. Mostly, the teacher asks students to create groups consist of two until four students then gives them topic and tasks to discuss. Moreover, the teacher talks too much during teaching-learning process and does not give enough opportunity for students to practice. Based on this teachers' explanation, the teacher does not consider the appropriate technique used to make students involved in speaking activity actively and also how to increase students' willingness to speak in English without being asked first.

The teacher should apply an appropriate technique to maximize students' achievement in speaking. The technique should possible to involve students to speak in English actively. It means that the teacher must create a fun classroom situation that will encourage students to speak actively by their own desire and also enjoy the process without anxiety feeling. As Brown (2001: 269) says that it is the teachers' job to provide a warm classroom situation that will encourage students to speak. It can be said that students should get enough opportunities to practice, the more students get opportunities to practice their speaking, the more they will get confidence and possible to maximize students' speaking skill. In conclusion, teacher has important role as the facilitator who provide rich opportunities, adequate activities and good input for the students in the speaking classroom by using an appropriate technique.

There are various teaching techniques can be applied in teaching speaking. One of them is TeamsGames-Tournaments technique. TGT is a technique under the cooperative learning that place students in study groups consist of 3 to 6 students who have the ability, gender, and syllable or different race. In this technique the students will play games against students' from other teams to collect points ( Slavin, 1995: 13). Furthermore, Johnson et al. (2013:11) state that cooperative learning is a method where the students work in teams to maximize their own and other members learning. It means that by using this method the students are asked to cooperate with their friends and interact each other in doing their task. While in the learning process students will get enough opportunities to practice and develop their speaking skill. This opinion is supported by Bailey in Nunan ( 2003: 55), she states that one of the important way for teaching speaking is limiting teacher talk and provide more opportunities for students to talk by using team work.

There are reasons why TGT will be effective if it is applied in teaching speaking skill. First, TGT requires students work together in teams to solve the problems given by the teacher. It is supported by Ur (1991: 121) who states that one of the treatments that the teacher can do to solve students' speaking problems is group work. During the group work, students may share information they know and also get new information from other members. Second, TGT requires each member of the team to compete against members from other teams. This activity will give an equal opportunity to each students to practice their speaking skill individually and at the same time will minimize the gap between dominant and passive students. As Brown (2001: 275) proposes one of the principles to design speaking technique is by giving students opportunities to initiate oral communication. By giving chance to students to express their ideas, it will become a good exercise for their self-confidence to perform in public. Third, playing games is an interesting activity for students especially when it is conducted in the classroom during the learning process. As the research that has been conducted by Tang (2001: 435) where it found that learning speaking by using games have positive effect to develop students' speaking skill. In conclusion, this technique can become an appropriate technique to teach speaking since it involves students to work together and interact actively, get opportunities to develop their individual speaking ability, and solve their speaking problems by a fun classroom situation.

There are several studies that have been conducted related to TGT technique and show that this technique is effective to use in teaching English, especially speaking skill. The first study was conducted by Safwandi in 2016, he conducted an experimental research to find out the effect of TGT technique towards students' speaking achievement. The second study was conducted by Rahmawati in 2017, she did an action research study to improve the quality of teaching speaking and students' speaking skill by using TGT, and also to solve students' problems in speaking. Third, a study by Nasution that was conducted in 2017, she did an action research study to investigate whether the application of TGT technique will improve students' achievement in speaking. And the last is the study conducted by Yasin (2017), she conducted an experimental research to find out the effect of TGT and students' self-esteem towards student reading comprehension. Based on those previous studies, TGT technique is proved effective to be applied in teaching speaking and other English skills. However, all of them only focus on investigating the effect of TGT technique towards students' speaking and other English skills achievement without considering the other aspect of students which have the significant influence towards students' speaking skill, this aspect is the anxiety of students.

In this research, the researcher used TeamsGames-Tournaments (TGT) technique as the treatment to find out its effectiveness in teaching speaking. The researcher limited the problems into two variables, TGT technique was stated as the independent variable and speaking skill as dependent variable. In accordance with the standard of competency in schools' syllabus, report text was used as the teaching material for speaking skill. Moreover, this research was limited to find out the effect of Teams-Games-Tournaments (TGT) technique toward students' speaking skill on report text in the Second Year Students of SMA N 9 Padang. While, the research questions of this research is "Do the students who are taught by using Teams-Games-Tournaments (TGT) technique have better speaking skill than those who are taught by traditional technique?". Based on the research 
question, the alternative hypothesis $\left(\mathrm{H}_{\mathrm{a}}\right)$ of this research was the students who taught by using Teams-GamesTournaments (TGT) technique have better speaking skill of report text than students who taught by using traditional technique. And as the null hypothesis $\left(\mathrm{H}_{0}\right)$ was the students who taught by using Teams-Games-Tournaments (TGT) technique do not have better speaking skill of report text than students who taught by using traditional technique.

\section{METHOD}

The research was experimental research. There were two groups involved in this research; the first group was experimental group and the second was control group. The first group (experimental group) was taught by using Teams-Games-Tournaments (TGT) technique, and the other group was treated by using traditional technique used by teacher, in this case was small group discussion technique. The population was the second year students of science class at SMA N 9 Padang in the academic year of 2019/2020. The population was 154 students which were divided into five classes. The researcher took two classes as the sample and divided into the experiment class and control class. After teaching by using Teams-GamesTournaments (TGT) technique to the experimental class and Small Group Discussion technique to the control class, the researcher will give oral presentation test to the students in both classes to know the effect of treatment toward students' speaking skill. Students in both classes will receive a similar test then it will be presented in front of the class. This activity will be recorded and analyzed by the researcher. The result of data analyzed will be used as the data of speaking test. After getting the data, it will be analyzed by using normality testing, homogeneity testing, hypotheses testing, t-test, and analysis of variances.

\section{RESULT AND DISCUSSION}

Table 1. Descriptive Statistics of Students' Speaking Score

\begin{tabular}{cccccccc}
\hline Class & N & Mean & Max & Min & SD & Var & Sum \\
\hline Experiment & 30 & 69.13 & 86 & 50 & 8.77 & 76.88 & 2074 \\
\hline Control & 30 & 63.67 & 80 & 50 & 8.54 & 72.99 & 1910 \\
\hline
\end{tabular}

The Table 1 above is the descriptive statistics table of speaking score in experimental and control group. Data analysis of speaking skill was taken from the results of students' speaking test which was administered in experimental and control group after the implementation of techniques. The data was analyzed by using Ms Excel. Based on analysis, the maximum score of students speaking test in experimental class is 86 and the minimum score is 50. The mean score is 69.13 , the standard deviation is 8.77 and the variance is 76.88 . While, the maximum speaking score of students in control class is 80 and the minimum score is 50 . The mean score is 63.67 , the standard deviation is 8.54 and the variance is 72.99 . It can be concluded that the mean score of students speaking test in experimental class was higher than the students in control class.

To answer the research hypothesis about the effect of Teams-Games-Tournament Technique toward students' speaking skill, the data were analyzed by using ttest to the students' speaking score. The result is shown in Table 2.

Table 2. The Results of the Independent-Sample t-test for Speaking Score

\begin{tabular}{|c|c|c|c|c|c|c|c|c|c|c|}
\hline \multicolumn{5}{|c|}{$\begin{array}{c}\text { Levene's Test for Equality of } \\
\text { Variances }\end{array}$} & \multicolumn{6}{|c|}{ t-test for Equality of Means } \\
\hline & & \multirow[t]{2}{*}{$\mathrm{F}$} & \multirow[t]{2}{*}{ Sig. } & \multirow[t]{2}{*}{$\mathrm{t}$} & \multirow[t]{2}{*}{ df } & \multirow{2}{*}{$\begin{array}{l}\text { Sig. } \\
(2- \\
\text { tailed })\end{array}$} & \multirow{2}{*}{$\begin{array}{c}\text { Mean } \\
\text { Differenc } \\
\mathrm{e}\end{array}$} & \multirow[t]{2}{*}{$\begin{array}{l}\text { Std. Error } \\
\text { Difference }\end{array}$} & \multicolumn{2}{|c|}{$\begin{array}{l}\text { 95\% Confidence } \\
\text { Interval of the } \\
\text { Difference }\end{array}$} \\
\hline & & & & & & & & & Lower & Upper \\
\hline \multirow{2}{*}{$\begin{array}{l}\text { Speaking } \\
\text { Score }\end{array}$} & $\begin{array}{l}\text { Equal } \\
\text { variances } \\
\text { assumed }\end{array}$ & .052 & .820 & 2.446 & 58 & .018 & 5.467 & 2.235 & .993 & 9.941 \\
\hline & $\begin{array}{l}\text { Equal } \\
\text { variances not } \\
\text { assumed }\end{array}$ & & & 2.446 & 57.961 & .018 & 5.467 & 2.235 & .993 & 9.941 \\
\hline
\end{tabular}

The table shows that there is a significant difference between stuents' score in control and experiment class. Teams-Games-Tournament Technique significantly give a better result towards students speaking score compared with Small Group Discussion Technique. The result shows that $\mathrm{t}_{\text {observed }}(58)=2.446$ while the critical $\mathrm{t}_{\text {table }}(58)=1.671$ with significant is 0.018 which lower than $0.05(\operatorname{sig}<\propto)$. It means that $t_{\text {observed }}>t_{\text {table. So, }}$ statistically $\mathrm{H}_{0}$ is rejected and $\mathrm{H}_{\mathrm{a}}$ is accepted for hypothesis of this research.

Then, the probability of significance value is less than the specified alpha value $(\operatorname{sig}<\propto)$, it shows that the $t_{\text {observed }}$ is significant. So, the students whowere taught by using Teams-Games-Tournament Technique got significantly better result in speaking test than those who were taught by using Small Group Discussion Technique at the second year students of SMA N 9 Padang. 


\section{CONCLUSION}

The using of an appropriate technique in teaching speaking are able to maximize students' achievement. It was proved by the result of this research which indicated that students in experimental class achieved significantly higher scores in speaking test than students in control class. The using of this technique is able to solve students' problems in speaking and increase their speaking skills. By generate opportunities for students to use English in a comfortable way, students do not feel burdened in learning and more relax to speak, and finally will develop their speaking skills. Students are also motivated to win the games and earn the points for their team by answer well the questions. It will encourage students to focus and pay attention to the materials using for games while teacher presentation.

To sum up, Teams-Games-Tournament Technique is an effective technique to use in teaching speaking because this technique is possible to involve students to speak in English actively.

\section{ACKNOWLEDGMENTS}

The researcher got a lot of helpful contributions from many people during the process of this research. As the expression of my gratitude, I would like to convey my greatest appreciation to my advisors Prof. Dr. Mukhaiyar, M.Pd and Dr. Ratmanida, M.Ed., TEFL for their valuable guidance and expertise. And also to the students and English teacher in SMA N 9 Padang for their support in conducted this research.

\section{REFERENCES}

[1] Brown, H. Douglas., \& Gillian Yule. 1983. Teaching Spoken Language. Cambridge: Cambridge University Press.

[2] Brown, H. Douglas. 1994. Teaching Speaking through Picture. New York : Me Grow-Hill Book Company.

[3] Brown, H. Douglas. 2000. Principles of Language Learning and Teaching $4^{\text {th }}$ edition. New York : Pearson Education.

[4] Brown, H. Douglas. 2001. Teaching by Principles: An Interactive Approach to Language Pedagogy $2^{\text {nd }}$ edition. New York : Longman.

[5] Brown, H. Douglas. 2004. Language Assessment: Principles and Classroom Practices. New York : Pearson Education.

[6] Brown, H. Douglas., \& Abeywickrama Priyanvada. 2010. Language Assessment: Principles and Classroom Practices $2^{\text {nd }}$ edition. New York: Pearson Education.

[7] Nunan, David. 2003. International Edition: Practical English Language Teaching $1^{\text {st }}$ edition. New York : McGraw Hill.

[8] Derewianka, Beverly. 1990. Exploring How Texts Work. New South Wales: Primary English Teaching Association.

[9] DeVries, D. L., Mescon, I. T., \& Shackman, S. L. 1975. Teams-Games-Tournament in the Elementary
Classroom: A Replication. Report No. 190. Baltimore, MD: The Johns Hopkins University. Retrieved from http://files.eric.ed.gov/fulltext/ED110885.pdf

[10] Fauzi, Imam. 2017. 'Improving Students' Speaking Ability through Small Group Discussion". JER, Journal of ELT Research, 2 (2): 130-138.

[11] Florez, M. A. 1999. "Improving Adult English Language Learners' Speaking Skills". ERIC Digest. (ERIC Document Reproduction Service No. ED: 435204 )

[12] Gibson, Jonathan. 2010. "Small Group Teaching in English Literature: A Good Practice Guide". The Higher Education Academy, No. 23. University of London: Royal Holloway.

[13] Hedge, Tricia. 2000. Teaching and Learning in the Language Classroom. New York: Oxford University Press.

[14] I.S.P. Nation., \& J. Newton. 2008. Teaching ESL/EFL Listening and Speaking. New York : Routledge.

[15] Jacobs, G.M., \& Ratmanida. 1996. "The Appropriacy of Group Activities: Views from some Southeast Asian Second Language Educators". RELC Journal, 27: 103-120.

[16] Lam Tang, Eunice Kit. 2001. "Developing Speaking Skill with Games: Towards a Cooperative Learning Approach". Proceedings of the 16th Conference of Pacific Association of Applied Linguistics. 434-435.

[17] Safwandi. 2016. "Teaching Speaking with the Teams-Games-Tournaments Technique". English Education Journal (EEJ), 7(2): 206-218.

[18] Slavin, Robert. E. 1991. Student Team Learning: A Practical Guide to Cooperative Learning , $3^{\text {rd }}$ edition. National Education Association of the United States.

[19] Slavin, Robert. E. 1995. Cooperative Learning. Theory, Research and Practice $2^{\text {nd }}$ edition. Boston: Allyn \& Bacon.

[20] Ur, Penny.1991. A Course in Language Teaching. Practice and Theory. Cambridge: Cambridge University Press.

[21] Yasin, Celly Casuarina. 2017. "The Effect of TeamsGames-Tournaments (TGT) Technique and Self Esteem on the students' Reading Comprehension at the Second Year Students of SMA Negeri 4 Pekanbaru". Unpublished Thesis. Padang: Magister Program Universitas Negeri Padang. 